\title{
Hexabenzocoronene Model Compounds for Asphaltene Fractions: Synthesis \& Characterization
}

Felaniaina Rakotondradany, ${ }^{a, b}$ Hicham Fenniri, ${ }^{b,{ }^{*}}$ Parviz Rahimi, ${ }^{c}$ Keith L. Gawrys, ${ }^{d}$ Peter K. Kilpatrick, ${ }^{d}$ Murray R. Gray, ${ }^{a, *}$

${ }^{a}$ Department of Chemical and Materials Engineering, University of Alberta, Edmonton, Alberta;

${ }^{\mathrm{b}}$ Department of Chemistry and National Institute for Nanotechnology, University of Alberta, Edmonton, Alberta;

${ }^{\mathrm{c}}$ National Centre for Upgrading Technology, Devon, Alberta;

${ }^{\mathrm{d}}$ Department of Chemical and Biomolecular Engineering, North Carolina State University, Raleigh, NC.

\section{Supporting Information}

$\begin{array}{ll}\text { I. Materials, Equipement, and Synthesis } & \text { S2 }\end{array}$

$\begin{array}{lll}\text { II. } & { }^{1} \mathrm{H}-\mathrm{NMR} \text { Titration experiment } & \text { S10 }\end{array}$

$\begin{array}{ll}\text { III. Vapor pressure osmometry } & \text { S10 }\end{array}$

IV. Differential scanning calorimetry and thermogravimetric analysis $\quad$ S11

$\begin{array}{ll}\text { V. Hot-stage microscopy measurements. } & \text { S11 }\end{array}$

$\begin{array}{ll}\text { VI. Small-Angle Neutron Scattering Measurements } & \text { S12 }\end{array}$

$\begin{array}{ll}\text { VII. Molecular Modelling } & \text { S14 }\end{array}$ 


\section{Experimental Section.}

Materials. All reagents were purchased from the Aldrich Chemical Co. The structures of the intermediates and the final products were confirmed by NMR spectroscopy and mass spectrometry.

Equipment. ${ }^{1} \mathrm{H}$ and ${ }^{13} \mathrm{C}$-NMR spectra were acquired on a Varian Inova 400 spectrometer. Electrospray ionization (ESI) mass spectra were acquired by direct infusion $(5 \mu 1)$ into HP Chemstation with the quadrupole voltage set to $3.5 \mathrm{kV}$, the source temperature $150-200^{\circ} \mathrm{C}$. Vapor pressure osmometry (VPO) measurements were carried out in toluene and in odichlorobenzene using a Knauer K-7000 osmometer. X-Ray diffraction data were collected using a Bruker D8 AXS Discover diffractometer, consisting of a step scanner equipped with a $1.2 \mathrm{~kW} \mathrm{CuK \alpha}$ tube $(\lambda=1.54 \AA)$ coupled to a silicon detector. Thermogravimetric analysis and differential scanning calorimetry were performed using a Luxx Netzsch STA 409 PC. Scanning electron microscopy (SEM) images were recorded on a Hitachi S-4800. Hot-stage microscopy measurements were carried out using a Zeiss Axioplan microscope equipped with cross polarizers. Temperature and pressure data were recorded using a video cassette recorder (VCR) and photomicrographs were taken using a video printer .

\section{Synthesis}

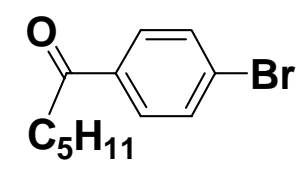


4-bromohexanoylbenzene. ${ }^{1}$ Hexanoyl chloride $(4.3 \mathrm{~g}, 31.8 \mathrm{mmol})$ was added dropwise to a solution of bromobenzene $(10.0 \mathrm{~g}, 63.6 \mathrm{mmol})$ and aluminum chloride $(5.0 \mathrm{~g}, 38.2 \mathrm{mmol})$. The reaction mixture was stirred at $50^{\circ} \mathrm{C}$ for $1 \mathrm{~h} 30$, then cooled to room temperature and poured into ice-water. Dichloromethane $(100 \mathrm{~mL})$ was added to the mixture, the organic layer was washed with $2 \mathrm{M} \mathrm{HCl}$ and brine, then dried using $\mathrm{Na}_{2} \mathrm{SO}_{4}$. The solvents were evaporated under reduced pressure and the resulting compound was used without further purification. $(11.0 \mathrm{~g}, 68 \%) .{ }^{1} \mathrm{H}-$ NMR (400 MHz, $\left.\mathrm{CDCl}_{3}\right) \delta 7.73\left(\mathrm{~d}, \mathrm{H}_{1}, 8 \mathrm{~Hz}\right), 7.54$ (d, $\left.\mathrm{H}_{2}, 8 \mathrm{~Hz}\right), 2.83\left(\mathrm{t}, \mathrm{H}_{3}, 7.5 \mathrm{~Hz}\right), 1.63$ (q, $\left.\mathrm{H}_{4}, 7.5 \mathrm{~Hz}\right), 1.33-1.07$ (m, $\left.\mathrm{H}_{5}\right), 0.89$ (t, $\left.3 \mathrm{H}\right)$. ESI-MS (pos): 254, 256.

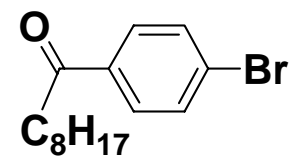

4-bromononoylbenzene. ${ }^{2}$ Prepared as described above for 4-bromohexanoylbenzene. Yield: 58 \%. ${ }^{1} \mathrm{H}-\mathrm{NMR}\left(400 \mathrm{MHz}, \mathrm{CDCl}_{3}\right) \delta 7.82\left(\mathrm{~d}, \mathrm{H}_{1}, 8 \mathrm{~Hz}\right), 7.50\left(\mathrm{~d}, \mathrm{H}_{2}, 8 \mathrm{~Hz}\right), 2.93\left(\mathrm{t}, \mathrm{H}_{3}, 7.5 \mathrm{~Hz}\right)$, 1.73 (q, $\mathrm{H}_{4}, 7.5 \mathrm{~Hz}$ ), 1.33-1.07 (m, $\mathrm{H}_{5}$ ), 0.89 (t, 3 H). ESI-MS (pos): 297, 299.

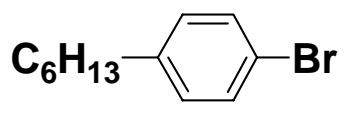

${ }^{1}$ van Bergen, M.; Gais, H.-J. J. Am. Chem. Soc. 2002, 124, $4321-4328$.

${ }^{2}$ Franks, S.; Hartley, F. R. J. Chem. Soc., Perkin Trans. 1, 1980, 10, 2233-2237. 
4-bromohexylbenzene 2a. ${ }^{3}$ 4-bromohexanoylbenzene (5 g, $\left.19.7 \mathrm{mmol}\right)$ was heated to reflux for $2 \mathrm{hr}$ in presence of hydrazine hydrate $(98 \%, 2.87 \mathrm{~mL})$ and potassium hydroxide $(4.41 \mathrm{~g}, 78.9$ $\mathrm{mmol})$ in triethylene glycol $(33 \mathrm{~mL})$. The reaction mixture was distilled at atmospheric pressure up to $210^{\circ} \mathrm{C}$. The residue was cooled to room temperature, poured into water, then acidified with concentrated $\mathrm{HCl}(20 \mathrm{~mL})$ and extracted with dichloromethane. The organic layer was washed with water and dried using $\mathrm{Na}_{2} \mathrm{SO}_{4}$. The solvents were evaporated under reduced pressure and the desired compound was isolated by column chromatography on silica gel using hexanes as eluent. (2 g, $42 \%) .{ }^{1} \mathrm{H}-\mathrm{NMR}\left(400 \mathrm{MHz}, \mathrm{CDCl}_{3}\right) \delta 7.40\left(\mathrm{~d}, \mathrm{H}_{1}, 8 \mathrm{~Hz}\right), 7.06\left(\mathrm{~d}, \mathrm{H}_{2}, 8 \mathrm{~Hz}\right), 2.58(\mathrm{t}$, $\left.\mathrm{H}_{3}, 7.5 \mathrm{~Hz}\right), 1.61$ (q, $\left.\mathrm{H}_{4}, 7.5 \mathrm{~Hz}\right), 1.33-1.07\left(\mathrm{~m}, \mathrm{H}_{5}\right), 0.89$ (t, $\left.\mathrm{H}_{6}\right)$.

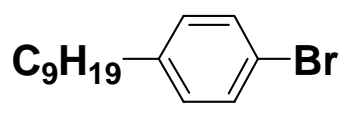

4-bromononylbenzene $2 a^{4}$ Prepared as described above for compound 2a. Yield: $24 \%$. ${ }^{1} \mathrm{H}-$ NMR (400 MHz, $\left.\mathrm{CDCl}_{3}\right) \delta 7.40\left(\mathrm{~d}, \mathrm{H}_{1}, 8 \mathrm{~Hz}\right), 7.06\left(\mathrm{~d}, \mathrm{H}_{2}, 8 \mathrm{~Hz}\right), 2.58\left(\mathrm{t}, \mathrm{H}_{3}, 7.5 \mathrm{~Hz}\right), 1.61$ (q, $\left.\mathrm{H}_{4}, 7.5 \mathrm{~Hz}\right), 1.33-1.07\left(\mathrm{~m}, \mathrm{H}_{5}\right), 0.89\left(\mathrm{t}, \mathrm{H}_{6}\right)$.

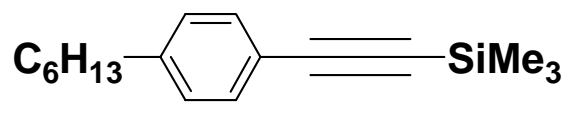

3 Terao, J.; Watanabe, H.; Ikumi, A.; Kuniyasu, H.; Kambe, N. J. Am. Chem. Soc. 2002, 124, $4222-4223$.

${ }^{4}$ Ikeue, T.; Aratani, N.; Osuka, A. Israel J. Chem. 2005, 45, 293-302. 
4-[(Trimethylsilyl)ethynyl]hexylbenzene 2aa. ${ }^{5}$ A solution of 4-bromohexylbenzene $(1 \mathrm{~g}, 4.1$ mmol) in piperidine $(27 \mathrm{~mL})$ was heated to $80{ }^{\circ} \mathrm{C}$ for $6 \mathrm{hrs}$ in presence of triphenylphosphine (107 mg, 0.41 mmol), copper iodide $(78 \mathrm{mg}, \quad 0.41 \mathrm{mmol})$, and transdichlorobis(triphenylphosphine)palladium(II) $\quad\left(\begin{array}{lllll}140 & \mathrm{mg}, & 0.20 & \mathrm{mmol}\end{array}\right)$ under argon. Trimethylsilylacetylene $(1.16 \mathrm{~mL}, 8.2 \mathrm{mmol})$ was added dropwise to the heated mixture. After cooling to room temperature, the reaction mixture was poured into a saturated $\mathrm{NH}_{4} \mathrm{Cl}$ solution and extracted with dichloromethane. The organic layer was washed with water and dried using $\mathrm{Na}_{2} \mathrm{SO}_{4}$. The solvents were evaporated under reduced pressure and the desired compound was isolated by column chromatography on silica gel using hexanes as eluent. (1.05 g, 99\%). ${ }^{1} \mathrm{H}-$ NMR (400 MHz, $\left.\mathrm{CDCl}_{3}\right) \delta 7.38\left(\mathrm{~d}, \mathrm{H}_{1}, 8.1 \mathrm{~Hz}\right), 7.10\left(\mathrm{~d}, \mathrm{H}_{2}, 8.1 \mathrm{~Hz}\right), 2.59$ (t, $\left.\mathrm{H}_{3}, 7.5 \mathrm{~Hz}\right), 1.58$ (q, $\left.\mathrm{H}_{4}, 7.5 \mathrm{~Hz}\right), 1.46-1.12\left(\mathrm{~m}, \mathrm{H}_{5}\right), 0.89\left(\mathrm{t}, \mathrm{H}_{6}\right), 0.25\left(\mathrm{~s}, \mathrm{H}_{7}\right)$. EI-MS: 259.

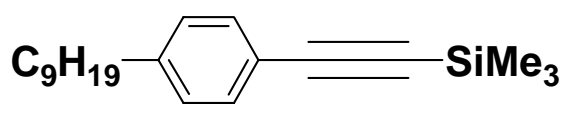

4-[(Trimethylsilyl)ethynyl]nonylbenzene 2ba. Prepared as described above for compound 2aa. Yield: 49 \%. ${ }^{1} \mathrm{H}-\mathrm{NMR}\left(400 \mathrm{MHz}, \mathrm{CDCl}_{3}\right) \delta 7.38\left(\mathrm{~d}, \mathrm{H}_{1}, 8.1 \mathrm{~Hz}\right), 7.10\left(\mathrm{~d}, \mathrm{H}_{2}, 8.1 \mathrm{~Hz}\right), 2.60(\mathrm{t}$, $\left.\mathrm{H}_{3}, 7.5 \mathrm{~Hz}\right), 1.58\left(\mathrm{q}, \mathrm{H}_{4}, 7.5 \mathrm{~Hz}\right), 1.30-1.12\left(\mathrm{~m}, \mathrm{H}_{5}\right), 0.88\left(\mathrm{t}, \mathrm{H}_{6}\right), 0.24\left(\mathrm{~s}, \mathrm{H}_{7}\right) .{ }^{13} \mathrm{C}-\mathrm{NMR}(100$ $\left.\mathrm{MHz}, \mathrm{CDCl}_{3}\right) \delta 143.55,131.75,128.29,120.15,93.13,35.78,31.77,29.09,22.55,13.99,-0.08$.

${ }^{5}$ Dingemans, T.; Photinos, D. J.; Samulski, E. T.; Terzis, A. F.; Wutz, C. J. Chem. Phys. 2003, 118, 7046-7061. 
Calculated (M/z): 300.2273. High resolution EI-MS: (M/z) 300.2278 (54 \%), 285.2040 (100 \%), $187.0941(13 \%)$.

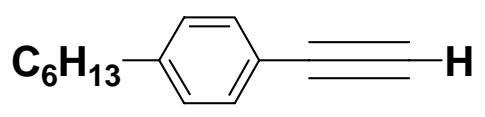

4- Ethynylhexylbenzene 3a. ${ }^{3}$ 4-[(Trimethylsilyl)ethynyl]hexylbenzene (1.05 g, $\left.4.1 \mathrm{mmol}\right)$ in DMF $(30 \mathrm{~mL})$ was stirred at room temperature overnight in presence of potassium fluoride $(475.7 \mathrm{mg}, 8.2 \mathrm{mmol})$ in water $(5 \mathrm{~mL})$. The reaction mixture was poured into water and extracted with dichloromethane. The organic layer was washed with water twice and dried using $\mathrm{Na}_{2} \mathrm{SO}_{4}$. The solvents were evaporated to dryness under vacuum and the desired compound was used without further purification. (747.6 mg, $98 \%)$. ${ }^{1} \mathrm{H}-\mathrm{NMR}\left(400 \mathrm{MHz}, \mathrm{CDCl}_{3}\right) \delta 7.38\left(\mathrm{~d}, \mathrm{H}_{1}\right.$, $8.1 \mathrm{~Hz}), 7.10\left(\mathrm{~d}, \mathrm{H}_{2}, 8.1 \mathrm{~Hz}\right), 3.03\left(\mathrm{~s}, \mathrm{H}_{7}\right), 2.59$ (t, $\left.\mathrm{H}_{3}, 7.5 \mathrm{~Hz}\right), 1.58$ (q, $\left.\mathrm{H}_{4}, 7.5 \mathrm{~Hz}\right), 1.46-1.12(\mathrm{~m}$, $\left.\mathrm{H}_{5}\right), 0.89\left(\mathrm{t}, \mathrm{H}_{6}\right)$. Calculated (M/z): 186.3. EI-MS: 187.0.

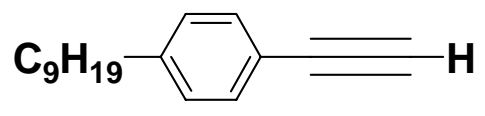

4- Ethynylnonylbenzene $3 \mathbf{b} .{ }^{6}$ Prepared as described above for compound 3a. Yield: $98 \%$. ${ }^{1} \mathrm{H}$ NMR (400 MHz, $\left.\mathrm{CDCl}_{3}\right) \delta 7.38\left(\mathrm{~d}, \mathrm{H}_{1}, 8.1 \mathrm{~Hz}\right), 7.10\left(\mathrm{~d}, \mathrm{H}_{2}, 8.1 \mathrm{~Hz}\right), 3.03\left(\mathrm{~s}, \mathrm{H}_{7}\right), 2.59\left(\mathrm{t}, \mathrm{H}_{3}, 7.5\right.$ $\mathrm{Hz}), 1.58\left(\mathrm{q}, \mathrm{H}_{4}, 7.5 \mathrm{~Hz}\right), 1.46-1.12\left(\mathrm{~m}, \mathrm{H}_{5}\right), 0.89\left(\mathrm{t}, \mathrm{H}_{6}\right)$.

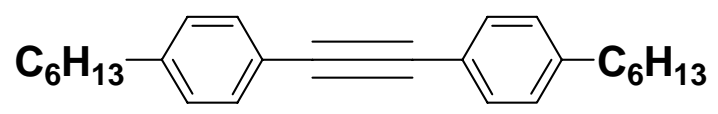

${ }^{6}$ Hughes, J. R.; Luckhurst, G. R.; Praefcke, K.; Singer, D.; Tearle, W. M., Mol. Cryst. \& Liq. Cryst. 2003, 396, 187-225. 
4,4'- Dihexyldiphenylacetylene 4a. A solution of 4-bromohexylbenzene (490 mg, $2.01 \mathrm{mmol})$ in piperidine $(10 \mathrm{~mL})$ was heated to $50^{\circ} \mathrm{C}$ in presence of copper iodide $(38 \mathrm{mg}, 0.2 \mathrm{mmol})$ and tetrakis(triphenylphosphine)palladium(0) $(92 \mathrm{mg}, 0.08 \mathrm{mmol})$ under argon. A solution of 4ethynylhexylbenzene $(1.77 \mathrm{~g}, 8.9 \mathrm{mmol})$ in piperidine $(9 \mathrm{~mL})$ was added dropwise to the heated mixture. The reaction mixture was kept at $80^{\circ} \mathrm{C}$ for $24 \mathrm{hrs}$. After cooling to room temperature, the reaction mixture was poured into a saturated $\mathrm{NH}_{4} \mathrm{Cl}$ solution and extracted with dichloromethane. The organic layer was washed with water and dried using $\mathrm{Na}_{2} \mathrm{SO}_{4}$. The solvents were evaporated under reduced pressure and the desired compound was isolated by column chromatography on silica gel using hexanes as eluent. (434 mg, $63 \%$ ). ${ }^{1} \mathrm{H}-\mathrm{NMR}$ (400 $\left.\mathrm{MHz}, \mathrm{CDCl}_{3}\right) \delta 7.40\left(\mathrm{~d}, \mathrm{H}_{1}, 8.1 \mathrm{~Hz}\right), 7.10\left(\mathrm{~d}, \mathrm{H}_{2}, 8.1 \mathrm{~Hz}\right), 2.59$ (t, $\left.\mathrm{H}_{3}, 7.5 \mathrm{~Hz}\right), 1.58\left(\mathrm{q}, \mathrm{H}_{4}, 7.5\right.$ $\mathrm{Hz}), 1.46-1.12\left(\mathrm{~m}, \mathrm{H}_{5}\right), 0.89\left(\mathrm{t}, \mathrm{H}_{6}\right) .{ }^{13} \mathrm{C}-\mathrm{NMR}\left(100 \mathrm{MHz}, \mathrm{CDCl}_{3}\right) \delta$ 143.16, 131.62, 128.37, 120.56, 88.87, 35.87, 31.65, 28.88, 22.55, 14.04. Calculated (M/z): 346.2661. EI-MS: 347.0 High resolution EI-MS: (M/z) 346.2664 (100 \%), 275.1756 (77 \%), 204.0944 (50 \%).

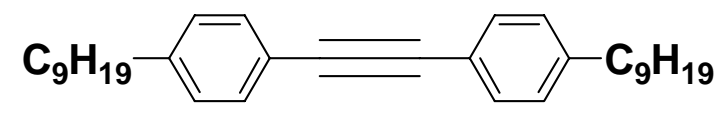

4,4'- Dinonyldiphenylacetylene $\mathbf{4 b}$. Prepared as described above for compound 4a. Yield: 83 \%. ${ }^{1} \mathrm{H}-\mathrm{NMR}\left(400 \mathrm{MHz}, \mathrm{CDCl}_{3}\right) \delta 7.40\left(\mathrm{~d}, \mathrm{H}_{1}, 8.1 \mathrm{~Hz}\right), 7.10\left(\mathrm{~d}, \mathrm{H}_{2}, 8.1 \mathrm{~Hz}\right), 2.59\left(\mathrm{t}, \mathrm{H}_{3}, 7.5 \mathrm{~Hz}\right)$, 1.58 (q, $\left.\mathrm{H}_{4}, 7.5 \mathrm{~Hz}\right), 1.46-1.12\left(\mathrm{~m}, \mathrm{H}_{5}\right), 0.89\left(\mathrm{t}, \mathrm{H}_{6}\right) .{ }^{13} \mathrm{C}-\mathrm{NMR}\left(100 \mathrm{MHz}, \mathrm{CDCl}_{3}\right) \delta$ 143.16, $131.62,128.37,120.56,88.87,35.87,31.65,28.88,22.55,14.04$. 


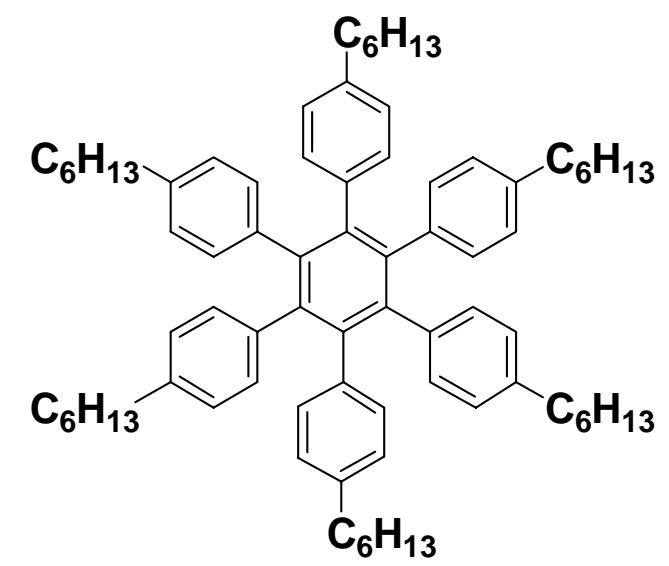

Hexakis-[4-hexylphen-1-yl]benzene 5a. A solution of 4,4'- dihexyldiphenylacetylene (512.1 $\mathrm{mg}, 1.48 \mathrm{mmol})$ in dioxane $(5 \mathrm{~mL})$ was heated to reflux for 1 day in presence of a catalytic amount of cobalt octacarbonyl. After cooling, the solvents were evaporated under reduced pressure and the desired compound was isolated by column chromatography on silica gel using $\mathrm{CH}_{2} \mathrm{Cl}_{2} /$ hexanes (1:9) as eluent. (229.8 mg, $\left.45 \%\right) . \quad{ }^{1} \mathrm{H}-\mathrm{NMR}\left(400 \mathrm{MHz}, \mathrm{CDCl}_{3}\right) \delta 6.64\left(\mathrm{~d}, \mathrm{H}_{1}\right.$, $8.1 \mathrm{~Hz}), 6.59$ (d, $\left.\mathrm{H}_{2}, 8.1 \mathrm{~Hz}\right), 2.30\left(\mathrm{t}, \mathrm{H}_{3}, 7.5 \mathrm{~Hz}\right), 1.58\left(\mathrm{q}, \mathrm{H}_{4}, 7.5 \mathrm{~Hz}\right), 1.46-1.12\left(\mathrm{~m}, \mathrm{H}_{5}\right), 0.89$ (t, $\left.\mathrm{H}_{6}\right)$. MS (pos): $1039{ }^{13} \mathrm{C}-\mathrm{NMR}\left(100 \mathrm{MHz}, \mathrm{CDCl}_{3}\right) \delta 140.16,138.89,138.16,131.27,126.32$, 35.23, 31.60, 31.04, 28.40, 22.52, 14.00. Calculated (M/z): 1038.8. MALDI-MS (using DCTB as matrix): $1038.8(100 \%)$.

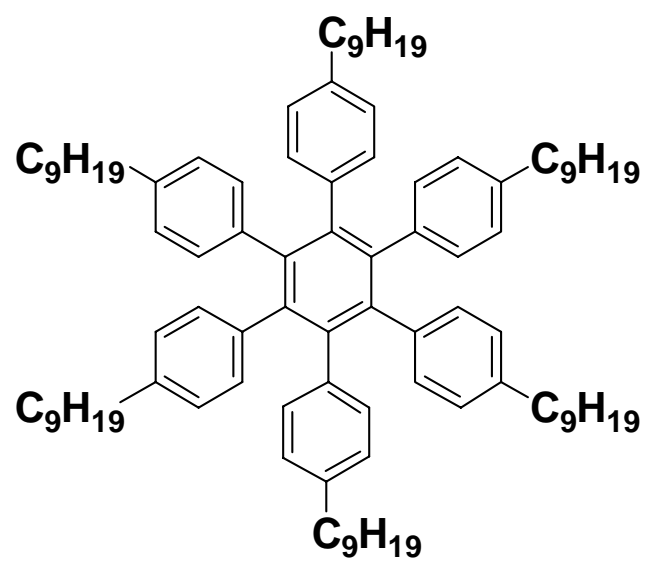


Hexakis-[4-nonylphen-1-yl]benzene 5b. Prepared as described above for compound 5a. Yield: $31 \% .{ }^{1} \mathrm{H}-\mathrm{NMR}\left(400 \mathrm{MHz}, \mathrm{CDCl}_{3}\right) \delta 6.64\left(\mathrm{~d}, \mathrm{H}_{1}, 8.1 \mathrm{~Hz}\right), 6.59\left(\mathrm{~d}, \mathrm{H}_{2}, 8.1 \mathrm{~Hz}\right), 2.30\left(\mathrm{t}, \mathrm{H}_{3}, 7.5\right.$ $\mathrm{Hz}), 1.58\left(\mathrm{q}, \mathrm{H}_{4}, 7.5 \mathrm{~Hz}\right), 1.46-1.12\left(\mathrm{~m}, \mathrm{H}_{5}\right), 0.89\left(\mathrm{t}, \mathrm{H}_{6}\right) .{ }^{13} \mathrm{C}-\mathrm{NMR}\left(100 \mathrm{MHz}, \mathrm{CDCl}_{3}\right) \delta$ 140.16, $138.89,138.16,131.27,126.32,35.23,31.60,31.04,28.40,22.52,14.00$. Calculated (M/z): 1292.1. MALDI-MS (using DCTB as matrix): 1291.0 (100\%). (\%) Calc. C 89.24, H 10.76. Found C 84.93, 10.60 (95.5\% purity due to the presence of residual hexanes).

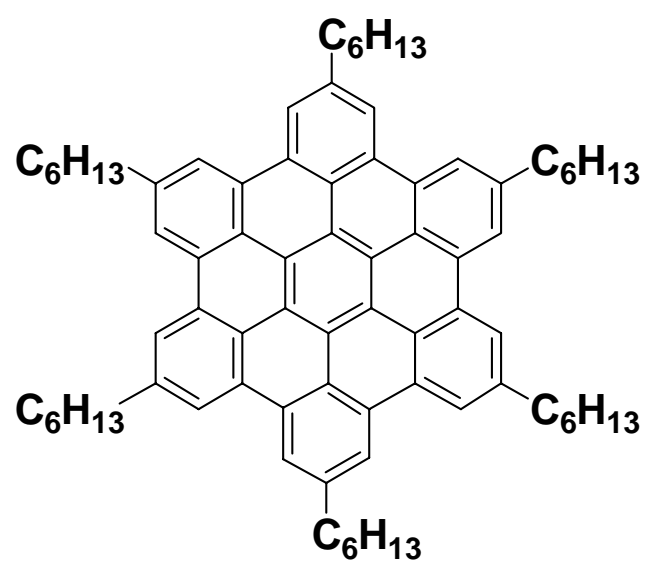

Hexa-hexyl-hexa-peri-hexabenzocoronene 1a. A solution of hexakis-[4-hexylphen-1yl]benzene $(200 \mathrm{mg}, 0.2 \mathrm{mmol})$ in dry dichloromethane $(5 \mathrm{~mL})$ was added to a solution of iron(III) chloride in anhydrous nitromethane. A flow of argon was bubbled through the reaction mixture for 30 mins. The solvents were evaporated under reduced pressure and the desired compound was isolated by column chromatography on silica gel using $\mathrm{CH}_{2} \mathrm{Cl}_{2} /$ hexanes (1:1) as eluent. (113 mg, 54 \%). ${ }^{1} \mathrm{H}-\mathrm{NMR}\left(400 \mathrm{MHz}, \mathrm{CDCl}_{3}\right) \delta 8.62\left(\mathrm{~s} \mathrm{br}, \mathrm{H}_{1}\right), 2.92\left(\mathrm{t}, \mathrm{H}_{2}, 7.5 \mathrm{~Hz}\right), 1.96$ (t, $\left.\mathrm{H}_{3}, 7.5 \mathrm{~Hz}\right), 1.46-1.12\left(\mathrm{~m}, \mathrm{H}_{4}\right), 0.89\left(\mathrm{t}, \mathrm{H}_{5}\right) .{ }^{13} \mathrm{C}-\mathrm{NMR}\left(100 \mathrm{MHz}, \mathrm{CDCl}_{3}\right) \delta$ 140.24, 127.68, $121.58,117.32,37.33,36.76,31.67,31.11,25.40,14.89$. Calculated (M/z): 1026.7. MALDI- 
MS (using DCTB as matrix): 1026.7 (100\%). (\%) Calc. C 91.17, H 8.83. Found C 82.87, 9.36 ( $92.7 \%$ purity due to the presence of residual toluene).

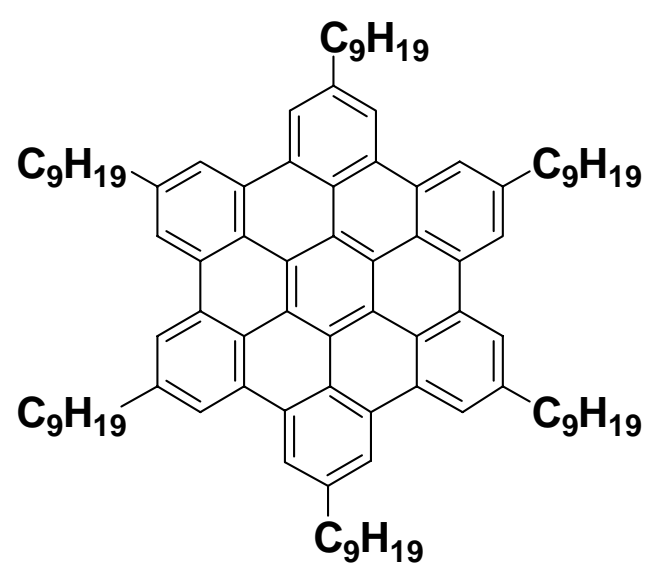

Hexa-nonyl-hexa-peri-hexabenzocoronene 1b. Prepared as described above for compound 1a Yield: $50 \%$. ${ }^{1} \mathrm{H}-\mathrm{NMR}\left(400 \mathrm{MHz}, \mathrm{CDCl}_{3}\right) \delta 8.62\left(\mathrm{~s} \mathrm{br}, \mathrm{H}_{1}\right), 2.92\left(\mathrm{t}, \mathrm{H}_{2}, 7.5 \mathrm{~Hz}\right), 1.96\left(\mathrm{t}, \mathrm{H}_{3}, 7.5\right.$ $\mathrm{Hz}), 1.46-1.12\left(\mathrm{~m}, \mathrm{H}_{4}\right), 0.89\left(\mathrm{t}, \mathrm{H}_{5}\right) .{ }^{13} \mathrm{C}-\mathrm{NMR}\left(100 \mathrm{MHz}, \mathrm{CDCl}_{3}\right) \delta$ 140.28, 125.95, 121.98, $113.10,38.42,38.20,35.50,31.80,39.59,22.57,14.00$. Calculated (M/z): 1280.0. MALDI-MS (using DCTB as matrix): 1282.4 (100\%). (\%) Calc. C 90.08, H 9.92. Found C 76.47, 9.56 (86.0 $\%$ purity due to the presence of residual toluene). 
${ }^{1}$ H-NMR titration experiment.

\begin{tabular}{|l|l|l|l|}
\hline $\begin{array}{l}\text { Concentration of } \mathrm{C}_{6}- \\
\mathrm{HBC}(\mathrm{mol} / \mathrm{L})\end{array}$ & $\begin{array}{l}{ }^{1} \mathrm{H}-\mathrm{NMR} \text { Chemical } \\
\text { shifts of aromatic } \\
\text { protons (ppm) }\end{array}$ & $\begin{array}{l}\text { Concentration of } \mathrm{C}_{6}- \\
\text { HBC (mol/L) }\end{array}$ & $\begin{array}{l}{ }^{1} \mathrm{H}-\mathrm{NMR} \text { 作 } \\
\text { shifts of } \\
\text { protons (ppm) }\end{array}$ \\
\hline $8.0757 \mathrm{e}-3$ & 8.6457 & $2.0305 \mathrm{e}-3$ & 8.8885 \\
$7.0663 \mathrm{e}-3$ & 8.7240 & $8.1287 \mathrm{e}-4$ & 8.9350 \\
$6.2811 \mathrm{e}-3$ & 8.7495 & $5.8062 \mathrm{e}-4$ & 8.9850 \\
$5.6530 \mathrm{e}-3$ & 8.7685 & $3.3869 \mathrm{e}-4$ & 9.0740 \\
$5.1391 \mathrm{e}-3$ & 8.8100 & $1.6238 \mathrm{e}-4$ & 9.1470 \\
$4.8733 \mathrm{e}-3$ & 8.8453 & $8.1189 \mathrm{e}-5$ & 9.1960 \\
$3.4809 \mathrm{e}-3$ & 8.8337 & $5.4126 \mathrm{e}-5$ & 9.1960 \\
$3.0458 \mathrm{e}-3$ & 8.8455 & $1.0000 \mathrm{e}-7$ & 9.1960 \\
$2.4366 \mathrm{e}-3$ & 8.9000 & & \\
\hline
\end{tabular}

Vapor pressure osmometry (VPO) measurements. A total of 8 different stock solutions of $\mathrm{C}_{6}-\mathrm{HBC}$ at concentrations ranging from $2 \mathrm{gL}^{-1}$ to $12 \mathrm{gL}^{-1}$ were prepared in toluene. $30 \mu \mathrm{L}$ of solution were injected into the osmometer chamber. After temperature equilibration (5 min), the voltage was recorded in $\mathrm{mV} .5$ independent measurements were made at each concentration, and the experiments were duplicated. A calibration curve was generated using benzil $(M=210.23)$ and polystyrene $(M=820)$ as molecular weight standards under the same conditions. Average molecular weight of studied aggregates were calculated using equation 1 :

$$
M W_{\text {unknown }} \times \lim _{C \rightarrow 0} \frac{V P O_{\text {unknown }}}{C_{\text {unknown }}}=M W_{\text {stan dard }} \times \lim _{C \rightarrow 0} \frac{V P O_{\text {stan dard }}}{C_{\text {stan dard }}}
$$




\section{Differential scanning calorimetry (DSC) and thermogravimetric analysis (TGA). The}

hexabenzocoronene samples $(5-10 \mathrm{mg})$ were heated under nitrogen atmosphere up to $600^{\circ} \mathrm{C}$ at a rate of $5^{\circ} \mathrm{C} / \mathrm{min}$ and then held at a constant temperature for $15 \mathrm{~min}$. One sample of $\mathrm{C}_{6}-\mathrm{HBC}(5$ $\mathrm{mg}$ ) was analysed according to the standard test method ASTM-D4530-85 designed for micro carbon residue of petroleum products to validate the pyrolysis yields at $500^{\circ} \mathrm{C}$.

Hot-stage microscopy measurements. $\mathrm{C}_{6}$ - $\mathrm{HBC}$ powders $(\sim 5 \mathrm{mg})$ were transferred in specially designed aluminum cup holders which were carefully placed into the cells and covered by a set of soft copper O-rings and a YAG (yttrium-aluminum-garnet) crystal. This allowed for the observation of mesophase development and subsequent transformation. The cell was also tightened to prevent the escape of volatiles during heating and was properly placed in the heated stage of the Zeiss Axioplan microscope.

The cell was connected through tubing to a gas system that supplied nitrogen at regulated pressures. In this study, the system was pressurized with $\mathrm{N}_{2}(500 \mathrm{psi})$ and the flow of the gas was maintained at $35 \mathrm{~mL} / \mathrm{min}$. The $\mathrm{C}_{6}-\mathrm{HBC}$ powders were heated from room temperature to $440^{\circ} \mathrm{C}$ at a rate of $2-5^{\circ} \mathrm{C} \min ^{-1}$. The cooling effect of the flowing gas made it necessary to adjust the furnace temperature upward by approximately $50^{\circ} \mathrm{C}$ to maintain the appropriate sample temperature. The appropriate sample temperature was confirmed by determining the melting points of $\mathrm{K}_{2} \mathrm{CrO}_{7}\left(\right.$ actual $\mathrm{mp}=398^{\circ} \mathrm{C}$, measured $\left.\mathrm{mp}=450^{\circ} \mathrm{C}\right)$ and $\mathrm{Zn}\left(\right.$ actual $\mathrm{mp}=419.47^{\circ} \mathrm{C}$, found $\mathrm{mp}=470^{\circ} \mathrm{C}$ ) under identical conditions used for bitumen fractions. The process was recorded by a video cassette recorder (VCR) for further observations.

Temperature and pressure data were recorded and displayed on the monitor. Photomicrographs were taken in polarized light under cross polars to show the optical texture of mesospheres and 
isochromatic regions. Although the microscope is equipped with interchangeable objectives, the $20 \times$ objective was chosen for convenience. The combined magnification of the system was $200 \times$.

Small-Angle Neutron Scattering Measurements. Two solutions of HBC were prepared in dtoluene (CDN Isotopes, 99.6 atom \% D). The final concentrations of the solution were $0.67 \%$ and $0.34 \%(\mathrm{w} / \mathrm{w})$. Small-angle neutron scattering measurements were performed using the small-angle neutron diffractometer (SAND) at the Intense Pulsed Neutron Source Division of Argonne National Laboratory (Argonne, IL). The available $Q$ range for the SAND instrument extended from 0.0035 to $2 \AA-1$. The absolute scattering intensity, $I(Q)$, for the sample was obtained from the total detector counts corrected for background radiation, neutron transmission through the samples, scattering from the quartz cells, and detector sensitivity.

A variety of models can be applied to the scattering intensity distribution, $I(Q)$, of an asphaltene solution in order to obtain information concerning the morphology of the scattered particle. The Guinier approximation ${ }^{7}$ provides a means of estimating aggregate sizes without specifying the particle geometry as given by:

$$
I(Q)=I_{0} \exp \left(-Q^{2} R_{G}^{2} / 3\right)
$$

where $\mathrm{I}_{0}$ is the scattering intensity extrapolated to $\mathrm{Q}=0 . \mathrm{R}_{\mathrm{G}}$ is the radius of gyration defined

as the root mean squared distance of all atoms from the center of mass of the particle. The zero-Q scattering intensity, $\mathrm{I}_{0}$, provides additional information concerning the particle geometry and is related to the weight-averaged molecular weight of the aggregates.

${ }^{7}$ Guinier A. Small Angle Scattering of X-rays; Wiley: New York, 1955. 
With a monodisperse system, ${ }^{8}$ the scattering intensity distribution is proportional to the product of an intra-particle structure factor, $P(\mathrm{Q})$, and an inter-particle structure factor, $S(\mathrm{Q})$, as given by:

$$
I(Q)=I_{0} P(Q) S(Q)=I_{0}|F(Q)|^{2} S(Q)
$$

where $|F(\mathrm{Q})|$ is the amplitude of the particle form factor. In the limit of low particle density, the solution becomes ideal and the inter-particle structure factor is assumed unity. The model presented here neglects interactions between particles. The amplitude of the particle form factor $|F(\mathrm{Q})|$ can be written as:

$$
|F(Q)|=\int\left[\rho_{p}(r)-\rho_{s}\right] \exp (i Q . r) d r
$$

where $\rho p(r)$ is the particle scattering length density at distance $r$ from the particle and $\rho$ s is the solvent scattering length density. The particle form factor is geometry dependent. Since particles are assumed to be randomly oriented, anisotropic particles must be averaged over spatial orientation.

The intra-particle structure factor for a monodisperse cylinder (oblate or prolate) with radius $\mathrm{R}$ and length $\mathrm{L}$ is given by:

$$
P_{c y l}(Q)=\int_{\beta=0}^{\pi / 2}\left[\frac{2 J_{1}(Q R \sin \beta)}{Q R \sin \beta} \frac{\sin ((Q L \cos \beta) / 2)}{(Q L \cos \beta) / 2}\right]^{2} \sin \beta d \beta
$$

${ }^{8}$ (a) Pedersen, J. S. Adv. Colloid Interface Sci. 1997, 70, 171-210. (b) Pedersen, J. S. J. Appl. Crystallog., 2000, 33, 637-640. 
where $J_{1}(x)$ represents a first order Bessel function of the first kind and $\beta$ is the orientational averaging angle. For a monodisperse oblate cylinder:

$$
P_{o b 1}(Q)=2\left[\frac{\sin (Q L / 2)}{(Q L / 2}\right]^{2}\left[\frac{1-J_{1}(2 Q R) / Q R}{(Q R)^{2}}\right]
$$

Alternatively, the high $\mathrm{Q}$ region of a monodisperse flat disk may also be described by an exponential approximation given by:

$$
P_{o b 2}(Q)=\frac{2}{(Q R)^{2}} \exp \left[-\frac{(Q L)^{2}}{12}\right]
$$

Molecular Modeling. The geometries of the $\mathrm{C}_{6}-\mathrm{HBC}$ monomers were fully optimized using the semi-empirical PM3 method within the Gaussian $03^{9}$ program package. Hexyl-substituted

${ }^{9}$ Gaussian 03, Revision C.02, Frisch, M. J.; Trucks, G. W.; Schlegel, H. B.; Scuseria, G. E.; Robb, M. A.; Cheeseman, J. R.; Montgomery, Jr., J. A.; Vreven, T.; Kudin, K. N.; Burant, J. C.; Millam, J. M.; Iyengar, S. S.; Tomasi, J.; Barone, V.; Mennucci, B.; Cossi, M.; Scalmani, G.; Rega, N.; Petersson, G. A.; Nakatsuji, H.; Hada, M.; Ehara, M.; Toyota, K.; Fukuda, R.; Hasegawa, J.; Ishida, M.; Nakajima, T.; Honda, Y.; Kitao, O.; Nakai, H.; Klene, M.; Li, X.; Knox, J. E.; Hratchian, H. P.; Cross, J. B.; Bakken, V.; Adamo, C.; Jaramillo, J.; Gomperts, R.; Stratmann, R. E.; Yazyev, O.; Austin, A. J.; Cammi, R.; Pomelli, C.; Ochterski, J. W.; Ayala, P. Y.; Morokuma, K.; Voth, G. A.; Salvador, P.; Dannenberg, J. J.; Zakrzewski, V. G.; Dapprich, S.; Daniels, A. D.; Strain, M. C.; Farkas, O.; Malick, D. K.; Rabuck, A. D.; Raghavachari, K.; Foresman, J. B.; Ortiz, J. V.; Cui, Q.; Baboul, A. G.; Clifford, S.; Cioslowski, J.; Stefanov, B. B.; Liu, G.; Liashenko, A.; Piskorz, P.; Komaromi, I.; Martin, R. L.; Fox, D. J.; Keith, T.; Al- 
hexabenzocoronene monomer was first optimised using the semi-empirical PM3 to generate a good input geometry for the face-packed system. Two minimum energy conformations were obtained for the $\mathrm{C}_{6}-\mathrm{HBC}$ monomer, consistent with the flexibility of the peripheral alkyl chains. (Figure 1) In the first conformation, the alkyl substituents point in the same direction resulting in a bowl-like geometry, while in the second conformation the alkyl chains point in opposite directions in an alternating fashion.
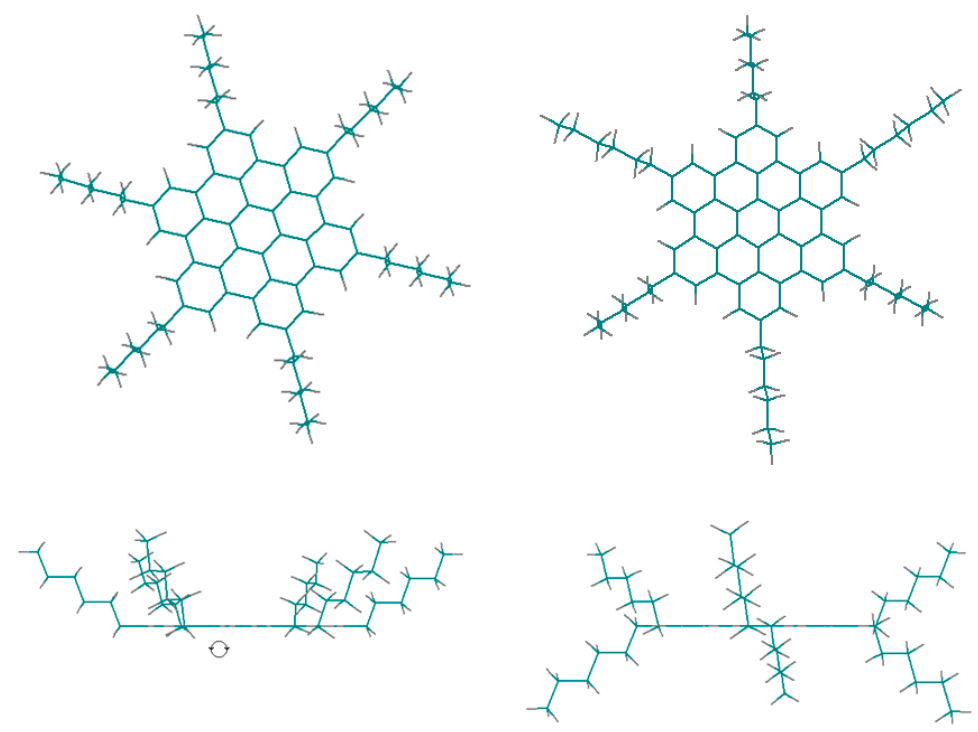

Figure 1. PM3 optimized geometries of bowl-like and alternating $\mathrm{C}_{6}-\mathrm{HBC}$.

Previous computational investigations of hexabenzocoronenes using DFT and higher level $a b$ initio methods were limited to the full optimisation of the unsubstituted monomer geometry, and the correlation of pi-stacking configurations with NMR data through simple single

Laham, M. A.; Peng, C. Y.; Nanayakkara, A.; Challacombe, M.; Gill, P. M. W.; Johnson, B.; Chen, W.; Wong, M. W.; Gonzalez, C.; and Pople, J. A.; Gaussian, Inc., Wallingford CT, 2004. 
point calculations ${ }^{10}$. These BP96 and HF computed structures reported in Table 1, along with our results, closely agree with the PM3 optimised $\mathrm{C}_{6}-\mathrm{HBC}$ structures, validating the use of PM3.

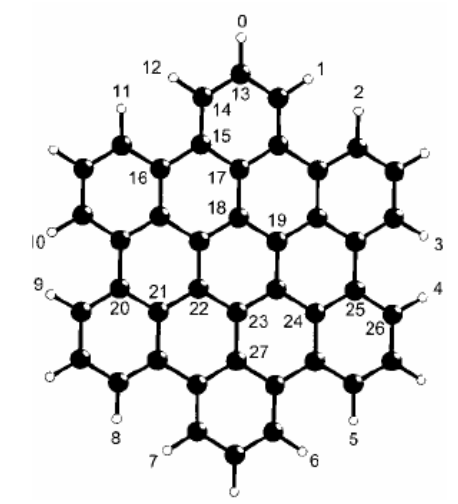

Table 1. Computed Structural Data for Hexabenzocoronene (HBC, $D_{6 h}$ Symmetry)

\begin{tabular}{lccc}
\hline & BP86/SVP & HF/SVP & PM3 \\
\hline$d(\mathrm{C} 13-\mathrm{C} 14)[\mathrm{pm}]$ & 139.6 & 137.9 & 139.1 \\
$d(\mathrm{C} 14-\mathrm{C} 15)[\mathrm{pm}]$ & 141.2 & 139.4 & 139.2 \\
$d(\mathrm{C} 15-\mathrm{C} 16)[\mathrm{pm}]$ & 146.5 & 146.9 & 145.6 \\
$d(\mathrm{C} 15-\mathrm{C} 17)[\mathrm{pm}]$ & 143.5 & 141.2 & 141.1 \\
$d(\mathrm{C} 17-\mathrm{C} 18)[\mathrm{pm}]$ & 145.1 & 145.7 & 144.3 \\
$d(\mathrm{C} 18-\mathrm{C} 19)[\mathrm{pm}]$ & 143.3 & 141.1 & 141.0 \\
$d(\mathrm{C} 13-\mathrm{H} 0)[\mathrm{pm}]$ & 110.0 & 108.2 & $\mathrm{~N} / \mathrm{A}$ \\
$d(\mathrm{C} 14-\mathrm{H} 12)[\mathrm{pm}]$ & 109.7 & 107.6 & 110.2 \\
$\angle(\mathrm{C} 14, \mathrm{C} 15, \mathrm{C} 17)$ & $119.2^{\circ}$ & $119.3^{\circ}$ & $120.9^{\circ}$ \\
$\angle(\mathrm{H} 12, \mathrm{C} 14, \mathrm{C} 15)$ & $120.2^{\circ}$ & $120.8^{\circ}$ & $119.2^{\circ}$ \\
$\angle(\mathrm{C} 15, \mathrm{C} 17, \mathrm{C} 18)$ & $120.4^{\circ}$ & $120.3^{\circ}$ & $120.3^{\circ}$ \\
\hline
\end{tabular}

${ }^{\text {a }}$ From Ref. 10.

${ }^{10}$ Ochsenfeld C., Brown S. P., Schnell I., Gauss J., Spiess H. W., J. Am. Chem. Soc., 2001, 123, 2597. 
Calculations for the packing of $\mathrm{C}_{6}$ - $\mathrm{HBC}$ were performed using the molecular mechanics $\mathrm{MM}^{+}$force-field applied to a rigid potential energy surface scan. ${ }^{11}$ (Figure 1) This empirical force field was used to evaluate the spatial arrangement of both PM3 optimised $\mathrm{C}_{6}$-HBC conformations because the predicted $\mathrm{MM}$ geometries can provide an accurate theoretical visualisation of molecular materials. ${ }^{12}$ A systematic sampling of the potential energy surface in terms of total energy $\mathrm{E}_{\text {tot }}$ was essential for determining the close-packed face-to-face arrangement of hexyl-substituted hexabenzocoronene. In this method, the total energy $E_{\text {total }}$ of each close-packed structure was therefore calculated as a function of (1) the relative rotation of the stacked rings about the z-axis, $\alpha,(2)$ the interplanar distances along the z-axis, $d_{\pi-\pi}$, and (3) the horizontal offset, $\mathrm{o}_{\pi-\pi}$. A one-dimensional array of two or three identical molecules were constructed along the z-axis with a starting intermolecular separation of $3.0 \AA .{ }^{13}$ Because of the 6-fold symmetry of the hexabenzocoronene monomers, the relative rotation of the aromatic rings about the z-axis, $\alpha$, was fixed at angles ranging between $0^{\circ}$ and $360^{\circ}$ for helical stacking and between $0^{\circ}$ and $360^{\circ}$ for non-helical arrangements; calculations were carried out at $5^{\circ}$ increments. For each angle $\alpha$, the total energy $\mathrm{E}_{\text {tot }}$ of the one-dimensional array was evaluated as

11 Rakotondradany, F. PhD Thesis, McGill University, 2004.

12 Boyd, D. B.; Lipkowski, K. B. J. Chem. Ed. 1987, 59, 269.

13 (a) Hunter, C. A.; Sanders, J. K. M. J. Am. Chem. Soc. 1990, 112, 5525. (b) Hunter, C. A.; Chem. Soc. Rev. 1994, 23, 101. (c) Adams, H.; Carver, F. J.; Hunter, C. A.; Osborne, N. J. Chem. Commun. 1996, 2529. (d) Adams, H.; Harris, K. D. M.; Hembury, G. A.; Hunter, C. A.; Livingstone, D.; McCabe, J. F. Chem. Commun. 1996, 2531. 
a function of the interplanar distance $\mathrm{d}_{\pi-\pi}$, and the horizontal inter-ring offset $\mathrm{o}_{\pi-\pi}$ to give low energy stacking configurations. The interplanar distance $\left(3.0 \AA<\mathrm{d}_{\pi-\pi}<6.9 \AA\right)$ was defined as the distance between each macrocycle with its direct neighbour along the z-axis; calculations were carried out at $0.1 \AA$ increments. The horizontal offset $\left(0 \AA<\mathrm{o}_{\pi-\pi}<5.6 \AA\right)$ was the distance between the macrocycle centres relative to the z-axis; calculations were performed at $0.1 \AA$ increments. Single point $\mathrm{E}_{\text {tot }}$ calculations were carried out using the empirical $\mathrm{MM}^{+}$force field contained in the HyperChem 5.1 program package.
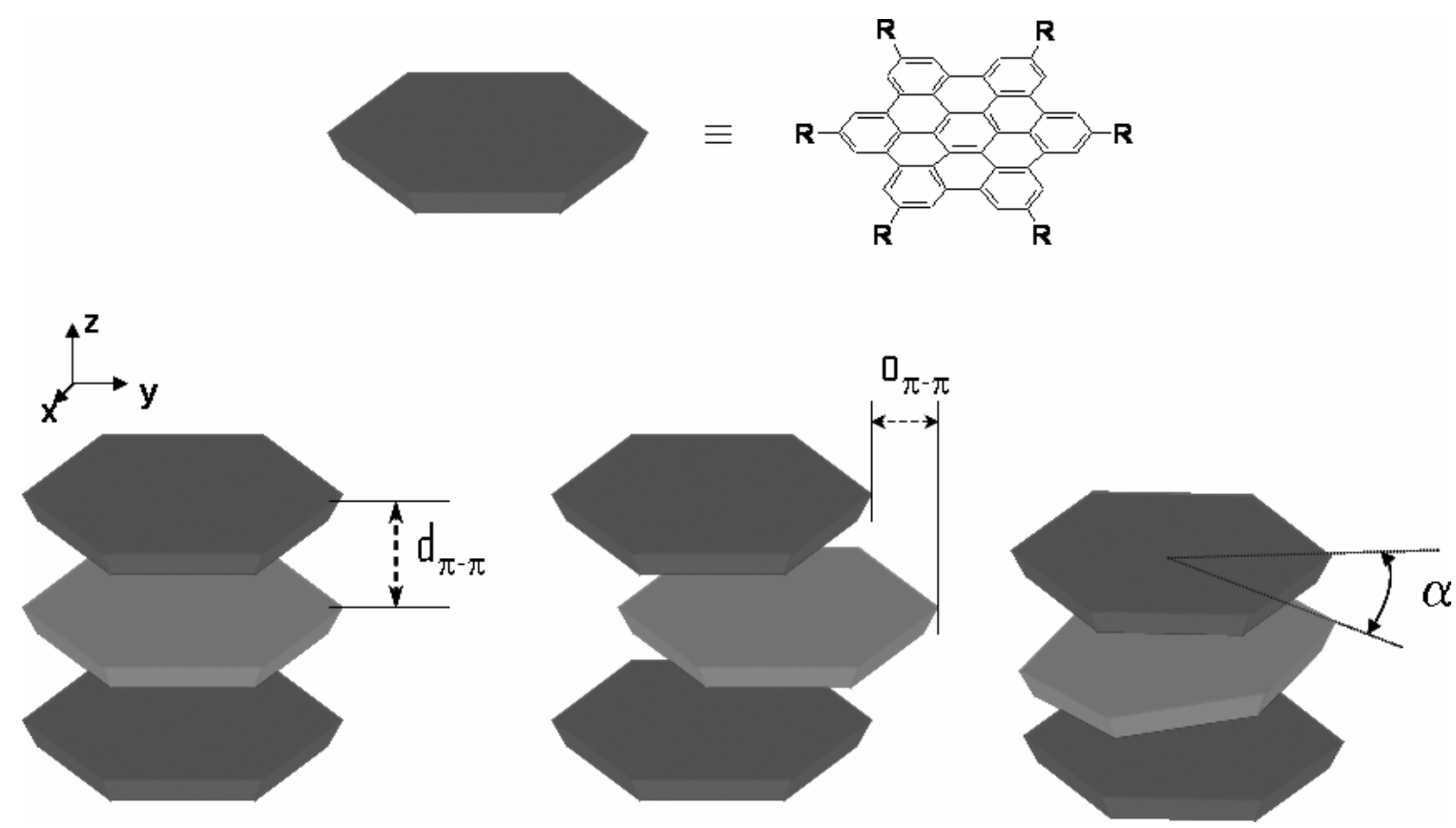

Figure 2. Representation of $\alpha$, the relative rotation of the aromatic rings about the $\mathrm{z}$-axis, $\mathrm{d}_{\pi-\pi}$, the interplanar distance along the $\mathrm{z}$-axis, and $\mathrm{o}_{\pi-\pi}$, the horizontal offset. 